\title{
Library, Library, Make Me a Match Impact of Form-Based Readers' Advisory on Academic Library Use and Student Leisure Reading
}

\section{Kaia Sievert, Amber Fick, Becky Adamski, Ashley Merrill, and Danika LeMay}

Kaia Sievert (ksievert@umn.edu), MLIS, is Multimedia Project Coordinator, University of Minnesota School of Public Health, formerly Library Assistant 2, University of Minnesota Libraries. Amber Fick (afick@siouxfalls.org), MLIS, is Librarian, Siouxland Libraries, formerly Library Assistant 2, University of Minnesota Libraries. Becky Adamski (adam0311@umn.edu) is Library Assistant 2, University of Minnesota Libraries. Ashley Merrill (kesxx023@umn.edu) is Library Assistant 3, University of Minnesota Libraries. Danika LeMay (stegos49@umn.edu), MFA, is Office Manager, Frontrunner Screen Printing, formerly Course Reserve Coordinator, University of Minnesota Libraries.

Reference \& User Services Quarterly, vol. 57, no. 4, pp. 254-65

(c) 2018 American Library Association. All rights reserved.

Permission granted to reproduce for nonprofit, educational use.
Staff from the Access and Information Services (AIS) department at the University of Minnesota Libraries developed several readers' advisory services to promote student engagement. One project was a Book Matchmaking service, for which users completed a web form and were given reading suggestions owned by the libraries. A brief survey was distributed to users of the service during the fall of 2016 to assess impact. The resulting data made a strong argument for further readers' advisory activities in academic libraries, as libraries and users benefit equally. Participating in the service encouraged positive engagement with the library and encouraged leisure reading.

I

n February 2015, a form-based readers' advisory service called Book Matchmaking was launched by a group of five staff members in the Access and Information Services (AIS) department at the University of Minnesota (U of M) Libraries. The service was intended to help library staff engage with users by learning about and encouraging their leisure reading habits and interests. Upon completing a simple online form on reading habits, participants from the university community received customized reading suggestions based on their responses. All offered reading suggestions were available for check out or as an e-book through the University Libraries, allowing the Libraries to highlight more recreational or "fun" materials available in our collections.

The Book Matchmaking service was promoted across multiple platforms within the Libraries and the university, such as the Libraries' homepage, social media accounts, and departmental and campus listservs. The $\mathrm{U}$ of $\mathrm{M}$ Libraries Book Matchmakers have received positive feedback from users expressing their appreciation for the service and for book suggestions. As of June 2017, more than seven hundred requests had been made, with several users returning to the form for additional customized reading suggestions.

We decided to take the data gathered from the service and complement it by conducting a survey of users of the service to assess its impact. As the data show, activities like the Book Matchmaking service encouraged users to interact with their campus libraries and had a positive impact on the higher education experience. We hope to share how the project worked and what we discovered to open a dialogue and encourage similar projects at other libraries. 


\section{LITERATURE REVIEW}

\section{History of Leisure Reading and Readers' Advisory in Academic Libraries}

Academic libraries have a history of promoting reading for pleasure. In the 1920s and 1930s, promoting leisure reading was seen as an important role for the academic librarian, as evidenced by an increase in research on student reading practices in the 1930s and 1940s. ${ }^{1}$ The golden era of readers' advisory in academic libraries was best captured by the browsing room and the residence hall library-collections of fiction and nonfiction works carefully curated by librarians to encourage students to read outside of their course syllabi, and put together in cozy library rooms with a readers' advisory desk staffed by a professional librarian or in an "open-access" collection inside residence halls. ${ }^{2}$

However, by the late 1940s and 1950s, interest in academic libraries promoting leisure reading began to decline due to increasing demands on budget and librarians' time and a focus on supporting classes and departments, among other reasons. ${ }^{3}$ By the 1970s, readers' advisory was on the decline, with limited attention given to the topic in library schools. ${ }^{4}$ In 1976, a survey was sent to all libraries that had reported having a residence hall library. Of the twenty-one libraries contacted, only twelve were still in operation and many reported closing due to lack of student interest, funding, and staffing, and to the loss of materials. ${ }^{5}$ In 1993, Janelle M. Zauha reported that while browsing rooms still existed in academic libraries, they were underfunded, unstaffed, rarely promoted, and often in hard-to-find locations. ${ }^{6}$

Interest in readers' advisory also decreased in public libraries during the mid-1900s. However, starting in the 1980s, particularly with the publication of guides such as Betty Rosenberg's Genreflecting and Joyce Saricks's Readers' Advisory Service in the Public Library, interest in promoting leisure reading experienced a renaissance in public libraries. ${ }^{7}$ While this renaissance in the 1980s and 1990s largely missed academic libraries, interest in the topic began to grow within professional literature during the early 2000s. We suggest this was perhaps motivated in part by three rather dire reports on literary reading habits among Americans released by the National Endowment for the Arts (NEA), the first of which was released in 2004, as most of the academic library readers' advisory articles we reviewed from this period cited one of these reports. The first report, Reading at Risk, found that literary reading declined among all American adults, but that the steepest decline was among the youngest age groups, who went from being one of the age groups most likely to read to least likely to read. Among Americans ages eighteen to twenty-four, 59.8 percent reported literary reading in 1982, while only 42.8 percent of this age group read in 2002, a rate of decline that was 55.0 percent greater than that of the general adult population. ${ }^{8}$
And while some contest that these NEA reports were overly alarmist, ${ }^{9}$ they appear to have pushed academic librarians to reconsider whether they should include promoting reading in the mission of the academic library. In her article, "Why Your Academic Library Needs a Popular Reading Collection Now More Than Ever," Dewan argues that "The next wave of recreational reading promotion strategies will emerge from academic libraries."10

\section{Why Leisure Reading Is Important}

Leisure reading is more than entertainment; it fosters skills that benefit students' academic success. Extra time spent reading improves students' academic skills, such as writing and critical thinking. Reading outside of assigned text has been connected with students' stronger writing skills. ${ }^{11}$

Studies have also shown that leisure reading can enhance critical thinking skills that are crucial not only to academic success, but to success in a democratic society. ${ }^{12}$ Readers of fiction must engage with a narrative by making connections between previous experiences and the text on the page. These connections are much richer than learning that occurs when reading a textbook solely for information. ${ }^{13} \mathrm{~A}$ number of studies have also found that reading fiction for pleasure has led to higher levels of empathy, an important quality in an increasingly global culture. ${ }^{14}$

\section{Importance of Readers' Advisory in an Academic Library}

There is a strong argument that students can benefit from the promotion of leisure reading. Likewise, there is also increasing evidence that promoting leisure reading will benefit the academic library. By incorporating leisure reading collections into academic libraries and providing both active and passive readers' advisory service, library staff can attract students to the library and begin to break down library anxiety. ${ }^{15}$ Many new college students are accustomed to finding books to read for fun in their public or school libraries. If students cannot find these books in the much larger campus library, their first visit to the academic library may become both disappointing and intimidating. ${ }^{16}$ In a similar vein, if students had the option of first engaging with reference librarians in a readers' advisory capacity, it may ease the transition into the more intimidating reference interview. ${ }^{17}$

Readers' advisory also benefits the academic library simply by bringing students in the door. In a survey of academic librarians, librarian Renee Hopkins described readers' advisory as "a hook to get students, faculty, and staff into the building." ${ }^{18}$ Students today have expectations for their college experience that go beyond simply earning an education. Universities are now striving to serve the "whole student." By providing a leisure reading collection, and promoting it to students, the academic library contributes to this goal. ${ }^{19}$ As a collection development policy from Sacramento State 


\section{FEATURE}

University suggests, leisure reading materials "provide users with a broad cultural background and ... in some way may enhance their lives... [supporting] the University's commitment to all dimensions of student life." 20

\section{Challenges to Readers' Advisory Efforts in Academic Libraries}

While the benefits of promoting popular literature and leisure reading in an academic library are substantial, there are also considerable barriers to providing this service. In a time when all libraries are struggling with shrinking budgets and limited staffing, it can be hard to justify providing a service that does not explicitly meet the academic goals of the larger institution. In a survey conducted by Elliott, 70 percent of academic library deans and directors surveyed reported that budget was a major barrier to promoting leisure reading. Sixty-five percent of respondents to the same survey said that inadequate staffing was also a major barrier. ${ }^{21}$ Finding additional shelf space for housing a leisure reading collection also proves difficult for many libraries.

With some creativity from library staff, however, these institutional barriers can be surmounted. Elliott suggests that overcoming a budget with no room to purchase special books can be as easy as finding what you already have in the collection and simply promoting its existence, such as books purchased for a young adult literature course. Partnering with local public libraries is also a low-budget and low-time solution. ${ }^{22}$

Another common barrier to selecting and promoting popular literature in an academic library is the belief that students do not read for fun. ${ }^{23}$ Anecdotally, we know many students lead very busy lives. However, while the stresses of balancing school, work, and a social life may not leave much time for pleasure reading, students may still be interested in leisure reading. A survey of undergraduate students at one liberal arts college found that more than 90 percent of undergraduates reported enjoying reading for fun but having limited time to do so due to demands of coursework and other competing priorities. When asked how the library could better help them overcome barriers to reading, the number one method suggested by students was providing book lists to help connect them with books to read. "This suggests that academic libraries may not need to address students' interest in recreational reading through collection development, but rather through some form of quick access reader's advisory geared to college students' interests." ${ }^{24}$

\section{INSTITUTIONAL CONTEXT}

Established in 1851, the University of Minnesota Twin Cities campus spans both Minneapolis and Saint Paul. According to the University's Office of Institutional Research, the total enrollment for the Twin Cities campus for Fall 2016 was 51,580 (30,975 undergraduate, 12,728 graduate, 3,661 professional programs, and 4,216 non-degree seeking students). ${ }^{25}$ The University of Minnesota Twin Cities also employed more than 23,000 faculty and staff during fiscal year $2016 .{ }^{26}$

The University Libraries encompass twelve campus locations and one library located at the Landscape Arboretum in Chaska, Minnesota. The Libraries house more than 8.2 million volumes, with Wilson Library being home to more than 3 million volumes. The collection in Wilson primarily falls within the arts, humanities, and social sciences. On an average semester weekday, Wilson Library has close to 3,100 users walk through its doors. Many come in to find a quiet place to study, to check out books they have requested, or to peruse the stacks. Students use the library as a meeting place to work on a group project, or to consult with a librarian in their subject. Because of the collections and traffic in Wilson Library, we were uniquely positioned to promote leisure reading on campus.

An ad-hoc group called From Our Collections formed in the summer of 2013 to create a bimonthly display that would promote leisure reading on campus. The group was composed of frontline staff from the AIS department in Wilson Library. The display would highlight the Robert and Virginia McCollister Collection for Contemporary Literature, a leased collection, along with materials owned by the libraries. Each display centered around a theme; for example, the first display focused on Beach Reads and the second on Banned Books. The Banned Books display drew the attention of a writer from the Minnesota Daily, the campus newspaper, and helped get the word out about looking to the libraries for leisure reading materials.

With the success of the bimonthly displays, the From Our Collections group considered other ways to promote leisure reading on campus, including a pop-up library in the fall of 2014 and a successful Blind Date with a Book event in February 2015. To coincide with the Blind Date with a Book event, we launched Book Matchmaking, our form-based readers' advisory service.

\section{FORM-BASED READERS' ADVISORY IN AN ACADEMIC LIBRARY}

Form-based readers' advisory is a service offered to library patrons; participants complete a form indicating their reading preferences and library staff curate personalized book suggestions for the patron. The concept was first developed in 2003 by Neil Hollands at Williamsburg Regional Library in Virginia. Hollands championed form-based readers' advisory as a method to overcome some of the limitations of both traditional face-to-face and passive readers' advisory. Formbased readers' advisory can attract patrons who may not otherwise approach library staff, allows for better suggestions by enabling the request to be routed to an appropriate staff member, and helps promote readers' advisory as a service offered by a library. ${ }^{27}$ 
Since the early 2000s, form-based readers' advisory has continued to grow in popularity. In 2013, a survey of 694 public libraries found that 19 percent of surveyed libraries reported offering form-based readers' advisory. ${ }^{28}$ And in 2014, Williamsburg Regional Library knew of 105 libraries offering a form-based service, with 85 additional libraries having shown interest in developing a service. ${ }^{29}$

Thus far, form-based readers' advisory has primarily existed within public libraries. However, we felt that formbased readers' advisory could be a useful tool in student engagement and readers' advisory in an academic library. We decided to test the concept in conjunction with our Blind Date with a Book display, which shaped the name of our service readers' advisory-Book Matchmaking.

Our team began this service to meet two main goals. First, we wanted to engage with the student body on a more personal and less intimidating level. By creating an online environment where library staff took time to respond to a request we hoped to demonstrate to students that library staff are a resource they can rely on. Next, we wanted to continue promoting the Libraries' popular reading collections, as popular fiction can be difficult to locate in an academic library. As service point staff, we had noticed a sizeable uptick in the number of users who would ask, "Where are the fun books?" or "Where is your literature section? I just want to browse," which often caught service point staff off guard. These are not easy questions to answer in an academic library, where books most likely do not have dust jackets and our literature books take up almost half of one floor. Clearly there was a need for readers' advisory in our library, and we felt that it was a need that we were well positioned to meet. With this service, service point staff were able to refer interested users to our Book Matchmaking form (and thus our group) if they felt uncertain offering readers' advisory.

The rollout of the Book Matchmaking service was quite popular. In the first week we received forty-seven submissions and decided to make the service available year-round, rather than just during the week surrounding the Blind Date with a Book display. Since then, we have steadily received requests.

Requests were submitted through a Google Form in which participants answered a series of questions about their reading habits. We asked participants to list three titles they recently enjoyed, select five characteristics from a list of appeal factors and genres, and share any other information that might be useful. Participants were also asked what kind of reading material they were looking for, such as fiction, nonfiction, poetry, or short stories. In general, we aimed to keep the form simple, relying on checkboxes instead of open-ended questions, in order to streamline the process for both participants and library staff.

To build the form, we brainstormed a list of characteristics (consisting of both genres and appeal factors) based on our own reading experiences, knowledge of readers' advisory practices, and example forms from multiple public library websites. We compared our list with appeal and subject terms in NoveList to identify any potential missing concepts, and then refined our list by combining similar terms. The final order of these characteristics was set to randomize. We also included an "other" option where participants could request a different or more specific characteristic. Our form grew and changed over time based on both responses to the "other" option, feedback from participants (who sometimes pointed out confusion surrounding a term), and new ideas from team members. By changing the form over time, we have made it less universal and more targeted to our particular community of readers. Some of the most popular characteristics included "lots of world building," "teaches me something new," and "interesting characters." The full form can be found in appendix A.

Submissions were collected in a Google Sheet that the whole team could access simultaneously. We made notes, listed recommendation ideas, and listed the final recommendations sent to each participant in the spreadsheet. While we all added ideas for suggestions, one person was assigned as the lead recommender for each request and made the final title selections. We used tools like Goodreads, NoveList Plus, Amazon.com, Genrify Blender, professional book reviews from Booklist or Kirkus Reviews, readers' advisory blogs, and the university library catalog to find books that matched a participant's tastes.

Final recommendations were added to an e-mail along with a short description of each book and why it was picked for the participant. Typically, each e-mail included three titles available from the University of Minnesota Libraries with direct links to the records in the library catalog. Occasionally, we recommended a book not held in the collection as a "bonus suggestion" and included information about how to request the book through Interlibrary Loan.

Our goal was to send recommendation e-mails within three business days of receiving a request. It was not always possible to meet that goal, especially in cases when more than sixty requests were received in a few days' time. Typically, we received a large volume of requests after the service was advertised in an e-mail newsletter sent to groups of students or university staff. We also received more requests after posting a link to the service on Libraries' social media. In cases when we could not fulfill the three-day promise, we tried to let requesters know about the delay.

Many participants submitted more than one request, and we sent new recommendations for each new request. Each e-mail included a link to a feedback form where participants could request additional recommendations if they had already read or disliked any of the titles provided. Overall, feedback through this channel was positive, with very few people requesting replacement recommendations.

Providing the service was a positive experience. We were able to offer the service because it was low-cost and low-risk. It did not cost anything to use library resources or Google products and to send e-mails. However, it did take considerable time to match participants with recommendations. Being a member of the team was not a requirement in any job description. In fact, most readers' advisory projects are 


\section{FEATURE}

accomplished only after primary job duties are completed. We were fortunate to have supportive management who encouraged us to try new programs and take risks.

Based on the large number of requests and positive feedback we have received informally, we wanted to have a better picture of the real impact of this service. To ascertain this impact, we created a survey that was sent to previous Book Matchmaking participants.

\section{METHODOLOGY}

We established two research questions to evaluate the effects of a form-based readers' advisory service:

Q1. How did participating in Book Matchmaking affect the users' relationship with the library?

Q2. How did participating in Book Matchmaking affect the users' leisure reading habits?

We hypothesized that participating in the Book Matchmaking service had a positive relationship with both variables considered-library use and leisure reading habits. Our team developed a survey to be sent to all users to test these hypotheses. The survey was developed in-house during the summer of 2016, and tested with a pilot group of nineteen people known to the testers but unfamiliar with the workings of the Book Matchmaking service. A few minor edits were made to the survey for clarity, based on feedback from the pilot group. The final survey consisted of sixteen multiple choice questions, one optional free response question, and four demographic questions (see appendix B for survey).

In December 2016, the survey was e-mailed to the 454 Book Matchmaking participants who completed a Book Matchmaking form between February 2015 and November 2016. Participants included undergraduate students, graduate students, university staff and faculty, alumni, and community users. The survey was open for three weeks, and a reminder was sent several days before the survey closed. All participants were informed that the survey was anonymous and voluntary, and no incentives were offered for participation. We received 165 responses, giving us a response rate of 36.3 percent. Two responses were removed because the respondents indicated they were under eighteen years of age.

We asked our survey participants standard questions about demographics, including age, gender, race/ethnicity, and affiliation with the Libraries. While the service was designed with students in mind, faculty and staff accounted for the highest percentage of responses (44.17\%), followed by undergraduate students $(25.15 \%)$ (see table 1$)$. Our respondents were overwhelmingly white (84.57\%) and female (86.42\%) (see tables 2 and 3). Ages were well-distributed, although

Table 2. Racial and/or Ethnic Identity of Book Matchmaking Respondents

Table 1. Respondents' Affiliation with Library

\begin{tabular}{lcc}
\hline Affiliation Type & Respondents & \% \\
\hline Faculty and staff & 72 & 44.17 \\
\hline Undergraduate student & 41 & 25.15 \\
Graduate or professional student & 28 & 17.18 \\
\hline Community members & 22 & 13.50 \\
\hline
\end{tabular}

\begin{tabular}{|c|c|c|c|c|c|c|c|c|c|c|}
\hline \multirow[b]{2}{*}{ Race/Ethnicity } & \multicolumn{2}{|c|}{$\begin{array}{l}\text { Undergraduate } \\
\text { Students }\end{array}$} & \multicolumn{2}{|c|}{$\begin{array}{l}\text { Graduate/ } \\
\text { Professional } \\
\text { Students }\end{array}$} & \multicolumn{2}{|c|}{ Faculty/Staff } & \multicolumn{2}{|c|}{$\begin{array}{l}\text { Community } \\
\text { Members }\end{array}$} & \multicolumn{2}{|c|}{ Total } \\
\hline & $\mathbf{n}$ & $\%$ & $\mathbf{n}$ & $\%$ & $\mathbf{n}$ & $\%$ & $\mathbf{n}$ & $\%$ & $\mathbf{n}$ & $\%$ \\
\hline $\begin{array}{l}\text { American Indian } \\
\text { or Alaska Native }\end{array}$ & 0 & 0 & 0 & 0 & 0 & 0 & 0 & 0 & 0 & 0 \\
\hline Asian & 5 & 11.11 & 3 & 9.68 & 4 & 5.48 & 0 & 0 & 12 & 7.02 \\
\hline $\begin{array}{l}\text { Black or African } \\
\text { American }\end{array}$ & 2 & 4.44 & 0 & 0 & 1 & 1.37 & 0 & 0 & 3 & 1.75 \\
\hline Hispanic or Latino & 3 & 6.67 & 3 & 9.68 & 3 & 4.11 & 0 & 0 & 9 & 5.26 \\
\hline $\begin{array}{l}\text { Middle Eastern or } \\
\text { North African }\end{array}$ & 0 & 0.00 & 0 & 0 & 0 & 0 & 0 & 0 & 0 & 0 \\
\hline $\begin{array}{l}\text { Native Hawaiian } \\
\text { or other Pacific } \\
\text { Islander }\end{array}$ & 1 & 2.22 & 0 & 0 & 0 & 0 & 0 & 0 & 1 & 0.58 \\
\hline White & 34 & 75.56 & 25 & 80.65 & 58 & 79.45 & 20 & 90.91 & 137 & 80.12 \\
\hline Other & 0 & 0.00 & 0 & 0 & 0 & 0 & 1 & 4.55 & 1 & 0.58 \\
\hline $\begin{array}{l}\text { Prefer not to } \\
\text { respond }\end{array}$ & 0 & 0.00 & 0 & 0 & 7 & 9.59 & 1 & 4.55 & 8 & 4.68 \\
\hline
\end{tabular}


65.64 percent were under the age of forty (see table 4). Of the undergraduate students, 78.05 percent were ages eighteen to twenty-two, which suggests that many students would fall under the category of "traditional" college students.

We were surprised by the percentage of responses received from faculty and staff. We did not start asking about relationship to the university (student, staff, faculty, etc.) until June 2016, over a year after the service started. However, the data we do have show that more students participated in the service than other groups. We find it intriguing that faculty and staff responded so well to the program and our survey. However, as the service was originally designed with undergraduate students in mind, we have limited the scope of our analysis for this paper largely on undergraduate students, and we will revisit the faculty and staff interest in our discussion.

\section{RESULTS}

\section{Reading and Library Use Habits}

First, we wanted to assess our participants' existing reading habits and typical library use. Our data suggest many of our undergraduate participants are already frequent library users. Most participants used the library either online or in person at least once a month: 85.37 percent reported visiting a library in person on at least a monthly basis and
82.92 percent reported using online library resources on a least a monthly basis (see figure 1). In fact, only one undergraduate reported that they visited the library in person and used online resources once per semester or less. Otherwise, all other undergraduate respondents (97.56 percent of undergraduate respondents) used the library in some format (in person or online) monthly or more frequently.

In addition to being frequent library users, our undergraduate respondents also had leisure reading habits. Of undergraduate respondents, 43.90 percent reported reading for pleasure an hour or more per week during the semester, and 92.69 percent of undergraduate respondents reported reading for pleasure for more than an hour per week during summer and school breaks. When comparing semester and school break reading habits, a clear relationship between the amount of time spent reading for pleasure and whether classes are in session or not is evident (see figure 2). Based on the data, it appears undergraduate students participating in the service were motivated to read for pleasure, but the stresses and demands of class negatively impact time spent reading for fun. This confirms Gilbert and Fister's finding that undergraduate students have high interest in leisure reading but little time for it. ${ }^{30}$

\section{Effects on Library Use}

Our first research question asked how participating in Book Matchmaking affected the users' relationships with the

Table 3. Gender Identity of Book Matchmaking Respondents

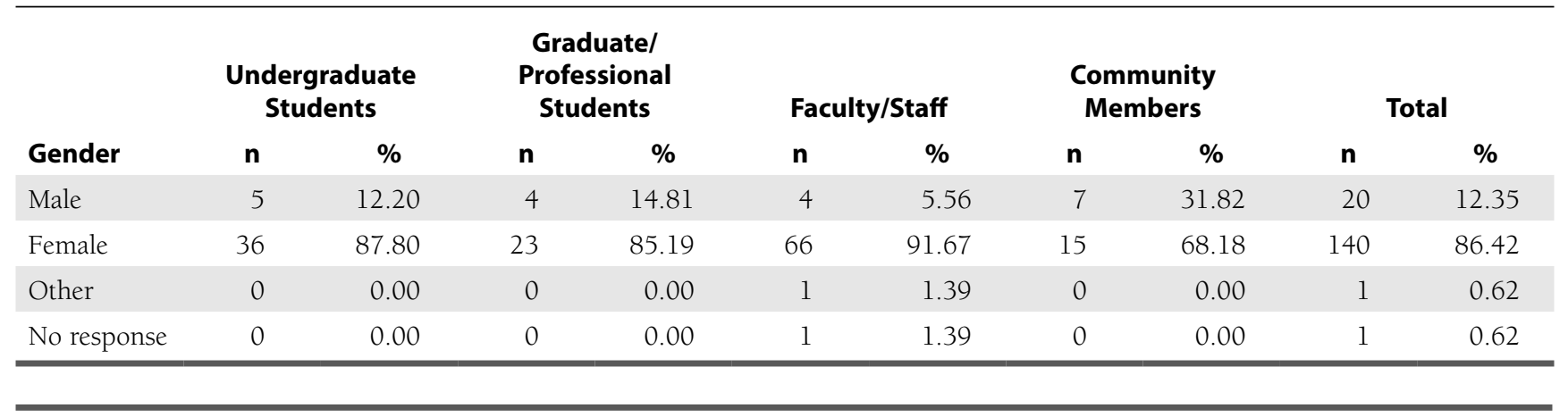

Table 4. Age of Book Matchmaking Survey Respondents

\begin{tabular}{|c|c|c|c|c|c|c|c|c|c|c|}
\hline \multirow[b]{2}{*}{ Age } & \multicolumn{2}{|c|}{$\begin{array}{l}\text { Undergraduate } \\
\text { Students }\end{array}$} & \multicolumn{2}{|c|}{$\begin{array}{l}\text { Graduate/ } \\
\text { Professional } \\
\text { Students }\end{array}$} & \multicolumn{2}{|c|}{ Faculty/Staff } & \multicolumn{2}{|c|}{$\begin{array}{c}\text { Community } \\
\text { Members }\end{array}$} & \multicolumn{2}{|c|}{ Total } \\
\hline & n & $\%$ & $\mathbf{n}$ & $\%$ & $\mathbf{n}$ & $\%$ & $\mathbf{n}$ & $\%$ & $n$ & $\%$ \\
\hline $18-22$ & 32 & 78.05 & 1 & 3.57 & 0 & 0.00 & 2 & 9.09 & 35 & 21.47 \\
\hline $23-29$ & 7 & 17.07 & 16 & 57.14 & 10 & 13.89 & 3 & 13.64 & 36 & 22.09 \\
\hline $30-39$ & 0 & 0.00 & 7 & 25.00 & 28 & 38.89 & 1 & 4.55 & 36 & 22.09 \\
\hline $40-49$ & 0 & 0.00 & 1 & 3.57 & 14 & 19.44 & 4 & 18.18 & 19 & 11.66 \\
\hline $50-59$ & 0 & 0.00 & 0 & 0.00 & 17 & 23.61 & 3 & 13.64 & 20 & 12.27 \\
\hline $60+$ & 2 & 4.88 & 3 & 10.71 & 3 & 4.17 & 9 & 40.91 & 17 & 10.43 \\
\hline
\end{tabular}




\section{FEATURE}

library. Data showed that 46.34 percent of undergraduate participants considered using the Libraries as a source of leisure reading, the lowest percentage following the public library (73.17\%), purchasing a book (63.41\%), and borrowing a book from a friend (51.22\%) (see figure 3).

Data also showed moderate support that participating in Book Matchmaking encouraged library use. Of undergraduates, 34.15 percent checked out at least one of their suggestions from the library, and 70.73 percent agreed that they would consider their university library for future leisure reading.

We also wondered whether outreach programs targeting reading for pleasure could help reduce library anxiety. While most of our participants were already frequent library users, 58.54 percent of undergraduates agreed that they were more likely to visit a $\mathrm{U}$ of $\mathrm{M}$ Library after participating in this service, and 41.46 percent agreed that they were more likely to ask a librarian a question after participating in the service.

\section{Effects on Leisure Reading Habits}

Our questions regarding reading habits demonstrated that Book Matchmaking participants were interested in reading for fun, but their ability to do so was limited during the semester. It is telling that almost half of our participants (43.90\%) made time for at least an hour of reading for fun even during the semester. Respondents to the survey did not need to be convinced that leisure reading is fun or beneficial. Nonetheless, our data showed our service did encourage participants to read for fun. Of undergraduate participants, 48.78 percent read at least one book suggested to them, and an additional 36.59 percent planned to read at least one when they had more time; 56.45 percent of all participants read at least one of our suggestions (see table 5). Additionally, 87.80 percent of undergraduates agreed that receiving their suggestions via e-mail encouraged them to pick up a book to read for fun, whether we had suggested it or not.

\section{Additional Insights}

We also gave survey participants the opportunity to share anything else they thought we might want to know about the service. Some comments offered constructive criticism. Several comments dealt with format (we did

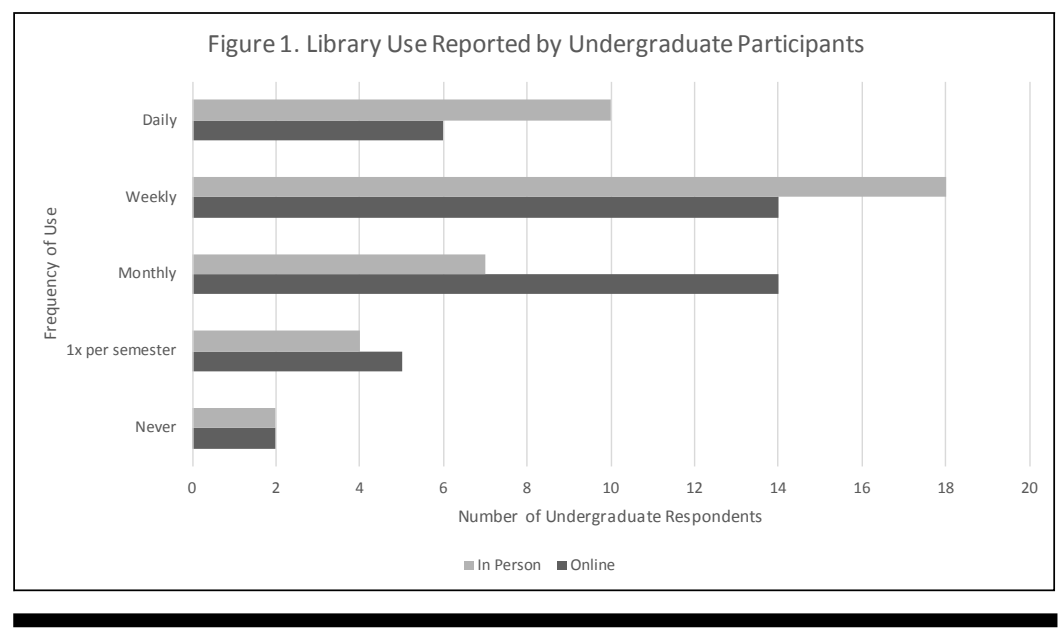

Figure 1. Library Use Reported by Undergraduate Participants

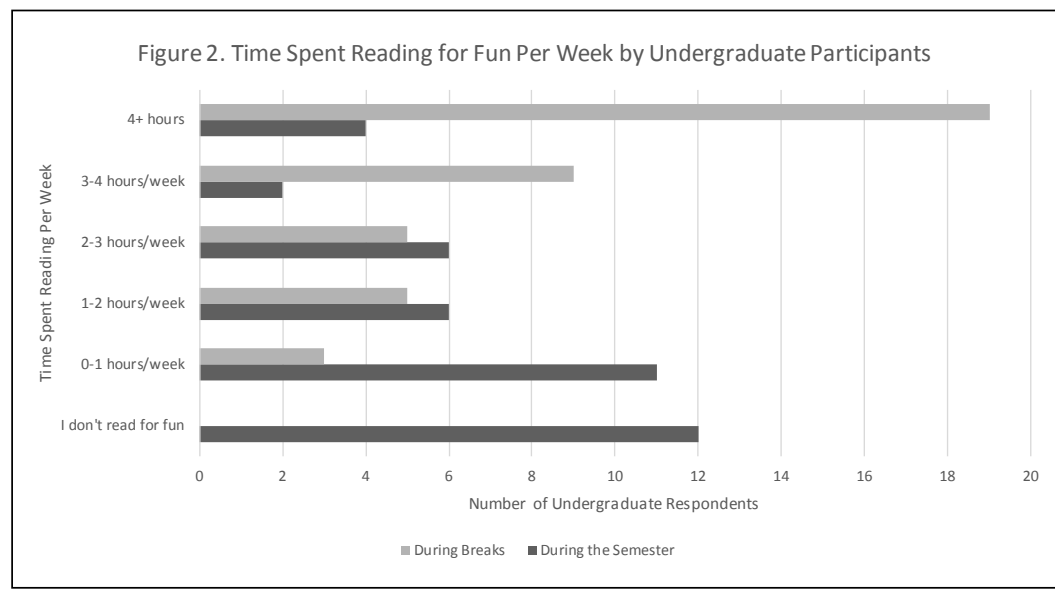

Figure 2. Time Spent Reading for Fun Per Week by Student Participants

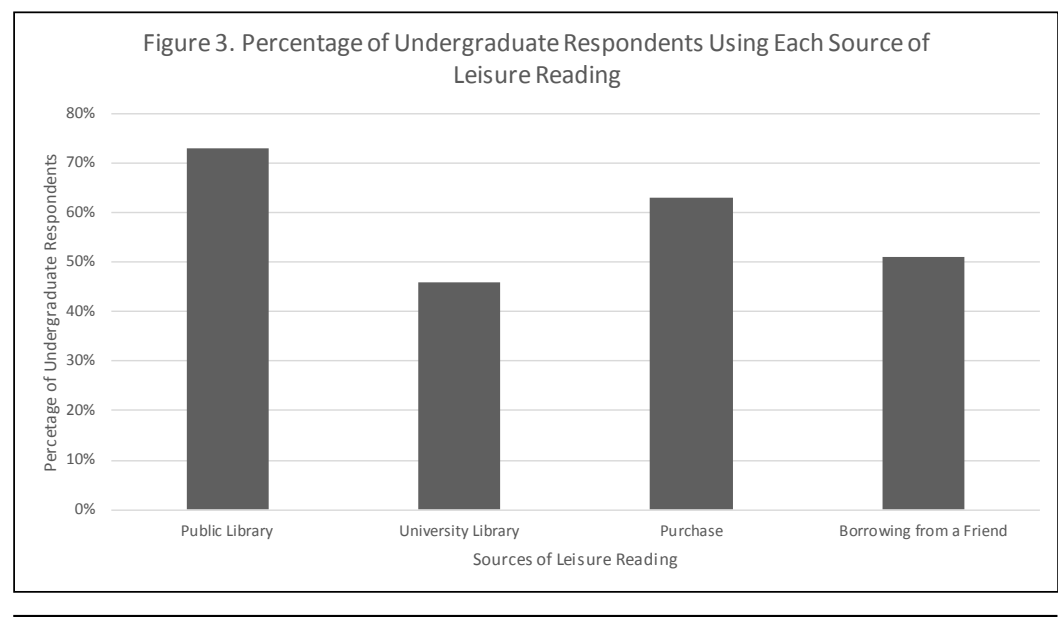

Figure 3. Percentage of Undergraduate Respondents Using Each Source of Leisure Reading

not offer many titles in e-book or audiobook formats), while others addressed frustrations with the existing structure of the library system (a short checkout period, confusion 


\begin{tabular}{|c|c|c|c|}
\hline & All Respondents (\%) & All Students (\%) & $\begin{array}{c}\text { Undergraduate } \\
\text { Students (\%) }\end{array}$ \\
\hline Yes, I read more than one & 34.36 & 31.88 & 21.95 \\
\hline Yes, I read one & 22.09 & 26.09 & 26.83 \\
\hline No, but I still plan on reading one or more when I have time & 34.97 & 27.54 & 36.59 \\
\hline No, I don't plan on reading any of the books suggested & 8.59 & 14.49 & 14.63 \\
\hline
\end{tabular}

using the catalog or requesting books from our campuses in other cities). And while there was a link to give immediate feedback or ask for different suggestions in the Book Matchmaking e-mail they received, some respondents gave feedback about their suggestions - that they had already read a book or were not interested in a particular suggestion-in the survey. Several responses also asked if we planned on running the service again and highlighted a need for better marketing to make it clear that the service runs year-round.

However, most responses were positive, expressing enjoyment of the service or sharing how many of the suggested books the user had read. One university staff member who participated highlighted the value of the service in encouraging leisure reading: "I loved the choices that were suggested to me, and went on to read many more books by those authors; two of which I hadn't encountered before. One author is now my favorite author!" Other comments highlighted the value of a readers' advisory service in building goodwill toward the library around campus. For example, one student shared, "I have raved about how clever, personal, and wonderful Book Matchmaking was to both other $\mathrm{U}$ of $\mathrm{M}$ students and to others (parents, friends from different universities, etc.). This was so fun!!" Finally, other respondents appreciated the help this service offered in managing information overload when trying to find books. Said one, "It's an innovative idea, and I wish that all library systems offered this service. There is so much information about books available online that it can be challenging to sift through it to find good options; being able to get a personalized response from someone who has knowledge about the kinds of books you like is really helpful." Qualitative responses like these support the value of the service and encourage similar endeavors.

\section{LIMITATIONS}

While our findings were promising, our study had several limitations. First, our survey sample was drawn solely from users who had voluntarily participated in our Book Matchmaking service and participating in the survey was also voluntary. Therefore, those who completed the survey self-selected twice, which may indicate an existing positive regard for the Libraries and leisure reading. Additionally, we did not have any pre-Book Matchmaking participation data for comparison; all measured effects of the program were self-reported by our users and could not be independently verified. Finally, we did not gather data from users who did not participate in Book Matchmaking for comparison. We believe our findings lend support for the benefit of promoting leisure reading in academic libraries, but our results should be considered an exploratory case study and warrant additional research into the relationship between participating in an academic library readers' advisory program and the effects on library use, library anxiety, or student success.

\section{DISCUSSION}

Our data confirmed our hypothesis that participating in Book Matchmaking had a positive relationship with measurements of library use and interest in engaging with the library in the future. We received positive response to questions regarding the impact of participating in the servicerespondents reported being more likely to visit a library and almost half agreed that they were more likely to ask a librarian a question after participating. While our data in this area were limited to a few questions, we believe our findings warrant further research on the potential impact of readers' advisory services on library anxiety.

We did discover we were reaching a slightly different audience than we expected. When we designed the service, we imagined reaching students who did not use the library regularly. To assess users' relationship with the University Libraries, participants were asked how often they visited the Library and how often they used online resources. More than 80 percent of respondents indicated that they were already heavy users of the print and digital resources offered by the Libraries. While this was positive data that Book Matchmaking participants had an existing relationship with the Libraries, it suggests that we may need to reframe our approach to the Book Matchmaking service. Instead of Book Matchmaking being a service to initiate a relationship, it may be argued that the service strengthens an existing one.

We were also surprised to see such high interest from faculty and staff, both in the Book Matchmaking service and in our survey. While a majority of participants in the Book Matchmaking service were students, nearly half of the respondents to our survey were faculty and staff. In part, this surprising quantity of staff participation may have stemmed from marketing methods, particularly with e-mails to the university community. Though predominantly advertised 


\section{FEATURE}

through communications from the University Libraries, one of our highest spikes in Book Matchmaking requests came after the service was highlighted through the official University of Minnesota staff and faculty weekly news digest. While we chose to focus on undergraduates for this paper, the enthusiastic response of faculty and staff demonstrate that libraries might also consider readers' advisory services as a tool for faculty and staff engagement.

Our data also support our hypotheses that participating in Book Matchmaking would have a positive effect on user's leisure reading habits; almost half of undergraduate participants read a book suggested by the service. One participant noted the value of Book Matchmaking in helping readers choose books, "I especially appreciate the Book Matchmaking because it is specifically bent towards recommending books based on books you already love. I can't tell you how many times I've finished a book/series and want something new, but with a similar feeling-it is difficult to find it on your own." And more practically, our data regarding student reading habits between semesters and on school breaks suggested that targeted readers' advisory services just before school breaks might be most effective, given students' time constraints.

Perhaps most compelling was the feedback that this was an enjoyable service to all users and that it did promote the role of the University Libraries in leisure reading. Many respondents commented that they had not considered using the University Libraries for leisure reading needs before, and of the sources respondents previously used to find books, the University Libraries were used the least. Nearly 71 percent of undergraduate students surveyed indicated that they would consider the University Libraries as a source of future leisure reading, which shows that the Book Matchmaking service has successfully connected students with the leisure reading content available in our collections.

\section{FUTURE DIRECTIONS}

Moving forward, we would like to continue to promote leisure reading among students. For example, we would like to focus on reaching a more diverse audience, as well as attracting more non-library users. Our survey results indicated that the majority of our respondents were white (84.57\%) and female $(86.42 \%)$ and that more than 80 percent already used the Libraries resources in some form at least once a month. By exploring other venues for promoting our Book Matchmaking service, our hope is that we can begin to bridge the gap and reach a more diverse audience.

One consideration that comes with increased marketing efforts, however, is the preparation needed to handle a larger influx of Book Matchmaking requests. Because every request takes time to fulfill and the Book Matchmakers have other job duties that take priority, high volumes of requests have resulted in e-mail blasts alerting participants that there may be a delay longer than the advertised two to three business days. While this is a definite way to address problematic periods of high volume requests, participants have sometimes waited a week to receive a response. Other approaches to handling a high volume of requests might be to look into bringing in additional staffing during high peak times or simply extending the advertised response time to four to five business days. Library staff will explore possible solutions as the Book Matchmaking service continues.

Lastly, our data suggest a potential positive relationship between the Book Matchmaking service and student wellness. Survey participants self-reported a positive interaction with the University Libraries and a positive correlation between involvement in the Book Matchmaking service and stress reduction. An encouraging 90.25 percent of undergraduates agreed that participating in Book Matchmaking was fun, and 58.54 percent agreed that participating in the service helped reduce their stress. While this is far from definitive evidence that promoting reading for fun helps students deal with the stresses and demands of college, it does warrant further investigation into the wider benefits of leisure reading programs. In future research, we would be interested in looking deeper into the effects involvement with the University Libraries and reading for leisure have on student well-being.

\section{CONCLUSION}

While the data collected yielded surprising results, we were affirmed in our hypotheses that resources like the Book Matchmaking service can foster goodwill between an academic library and its users. The program participants certainly found value in the service and in reading for leisure. The survey results will be invaluable for informing similar efforts to engage new library users and to continue to support the mission of the university to educate and drive innovation. We hope that the service and the data shared here will help inspire other academic libraries to embrace readers' advisory activities anew, as they have proven worthwhile and rewarding for the library and library users in this case.

\section{ACKNOWLEDGEMENTS}

We would like to thank Phil Dudas, Jackie Gulbranson, Kate Peterson, and Kirsten Clark for their support in both the program and research.

\section{References}

1. Janelle M. Zauha, "Recreational Reading in Academic Browsing Rooms: Resources for Readers' Advisory," Collection Building 12, no. 3/4 (1993): 57-62; Julie Elliott, "Academic Libraries and Extracurricular Reading Promotion," Reference \& User Services Quarterly 46, no. 3 (Spring 2007): 34-43.

2. Zauha, "Recreational Reading in Academic Browsing Rooms," 57-62; Susan Andriette Ariew, "The Failure of the Open Access Residence Hall Library," College \& Research Libraries 39, no. 5 (September 1978): 372-80 
3. Elliott, "Academic Libraries and Extracurricular Reading Promotion," 34-43; Zauha, "Recreational Reading in Academic Browsing Rooms," 57-62.

4. Elliott, "Academic Libraries and Extracurricular Reading Promotion," 34-43.

5. Ariew, "The Failure of the Open Access Residence Hall Library," 372-80.

6. Zauha, "Recreational Reading in Academic Browsing Rooms," 57-62.

7. Pauline Dewan, "Why Your Academic Library Needs a Popular Reading Collection Now More Than Ever," College \& Undergraduate Libraries 17, no. 1 (March 2010): 44-64; Barry Trott, introduction to "Academic Libraries and Extracurricular Reading Promotion," Reference \& User Services Quarterly 46, no. 3 (Spring 2007): 34.

8. National Endowment for the Arts, "Reading at Risk: A Survey of Literary Reading in America," June 2004, https://www.arts.gov/ sites/default/files/ReadingAtRisk.pdf.

9. Catherine Sheldrick Ross, Lynne E. F. McKechnie, and Paulette Rothbauer, Reading Matters: What the Research Reveals about Reading, Libraries and Community (Westport, CT: Libraries Unlimited, 2006), 17-26.

10. Dewan, "Why Your Academic Library Needs a Popular Reading Collection," 53.

11. Mary C. Daane, "Good Readers Make Good Writers: A Description of Four College Students," Journal of Reading 35, no. 3 (1991): 184-88; Heather Nicholson, "How to Be Engaging: Recreational Reading and Readers' Advisory in the Academic Library," Public Services Quarterly 8, no. 2 (2012): 178-86.

12. Nicholson, "How to Be Engaging," 178-86; Barbara MacAdam, "Sustaining the Culture of the Book: The Role of Enrichment Reading and Critical Thinking in the Undergraduate Curriculum," Library Trends 44, no. 2 (1995): 237-63.

13. MacAdam, "Sustaining the Culture of the Book," 237-63.

14. Raymond A. Mar, Keith Oatley, and Jordan B. Peterson, "Exploring the Link between Reading Fiction and Empathy: Ruling Out Individual Differences and Examining Outcomes," Communications: The European Journal of Communication Research 34, no. 4 (January 2009): 407-28; David Comer Kidd and Emanuele Castano, "Reading Literary Fiction Improves Theory of Mind," Science 342, no. 6156 (October 2013): 377-80; Loris Vezzali et al., "The Greatest Magic of Harry Potter: Reducing Prejudice," Journal of Applied Social Psychology 45, no. 2 (2015): 105-21.
15. Pauline Dewan, "Reading Matters in the Academic Library: Taking the Lead from Public Librarians," Reference \& User Services Quarterly 52, no. 4 (2013): 309-19; Nicholson, "How to Be Engaging," 178-86; Rochelle Smith and Nancy J. Young, "Giving Pleasure Its Due: Collection Promotion and Readers' Advisory in Academic Libraries," Journal of Academic Librarianship 34, no. 6 (November 2008): 520-26.

16. Nicholson, "How to Be Engaging," 178-86; Smith and Young, "Giving Pleasure Its Due," 520-26.

17. Nicholson, "How to Be Engaging," 178-86

18. Elliott, "Academic Libraries and Extracurricular Reading Promotion," 41.

19. Bette Rathe and Lisa Blankenship, "Recreational Reading Collections in Academic Libraries," Collection Management 30, no. 2 (April 2006): 73-85.

20. California State University Library, "California State University," in Library Development Policies: A Reference and Writers' Handbook, edited by Richard J. Wood and Frank Hoffman (Lanham, MD: Scarecrow Press, 1996), 100.

21. Elliott, "Barriers to Extracurricular Reading Promotion," 340-46.

22. Elliott, "Barriers to Extracurricular Reading Promotion," 340-46.

23. Elliott, "Barriers to Extracurricular Reading Promotion," 340-46.

24. Julie Gilbert and Barbara Fister, "Reading, Risk, and Reality: College Students and Reading for Pleasure," College \& Research Libraries 72, no. 5 (2011): 474-95.

25. "Campus and Unit Enrollment by Academic Level for Fall 2016," University of Minnesota Office of Institutional Research, accessed February 28, 2017, https://www.oir.umn.edu/student/enroll ment/term/1169/current/13422.

26. "University of Minnesota: Employee Head Count 2016," University of Minnesota Office of Institutional Research, accessed February 28, 2017, https://www.oir.umn.edu/hr/employee_count.

27. Neil Hollands, "Improving the Model for Interactive Readers' Advisory Service," Reference \& User Services Quarterly 45, no. 3 (Spring 2006): 205-12

28. "Readers' Advisory in Public Libraries Report," NoveList, 2013 , https://www.ebscohost.com/novelist/idea-center/evaluate/eval uate-state-of-readers-advisory.

29. Barry Trott, "Looking for a Good Book? Ten Years of FormBased Readers' Advisory at the Williamsburg Regional Library," NoveList, January 2014, https://www.ebscohost.com/novelist /novelist-special/looking-for-a-good-book.

30. Gilbert and Fister, "Reading, Risk, and Reality," 474-95.

\section{APPENDIX A. BOOK MATCHMAKING FORM University of Minnesota Libraries' Book Matchmaking Service}

Having trouble finding a book you really love? Looking for something fun or different in your reading life? Fill out this short form about your reading life, and our expert book matchmakers will e-mail you a list of three new books that match what you are looking for!

Name:

E-mail Address:

What are three books you read recently and loved? (please include author names, if possible):

Which of the following are you interested in reading?

$\square$ fiction

$\square$ nonfiction

$\square$ poetry

$\square$ short stories
Choose five qualities you look for in a book:

$\square$ adventure

$\square$ atmospheric

$\square$ based in reality (no unicorns for me!)

$\square$ black humor

$\square$ classics

. coming-of-age

$\square$ crime 


\section{FEATURE}

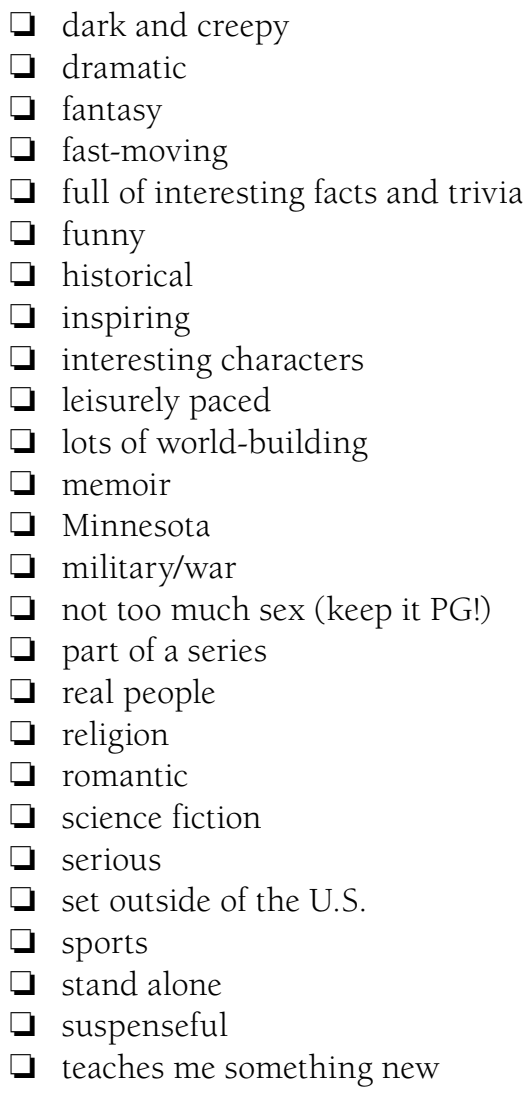

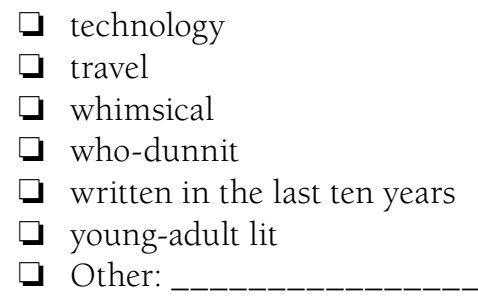

Anything else we should know?

How did you hear about this service?

$\square$ A link was sent in an e-mail I received

I I found it on the library website

- I heard about it at a library event/booth

$\square$ I heard about it at the library

$\square$ I saw it on social media

$\square$ A friend told me about it

$\square$ Other:

Are you a
$\square$ UMN Undergraduate Student
$\square$ UMN Graduate Student
$\square$ UMN Faculty/Staff
$\square$ UMN Alumni
$\square$ Friends of the Libraries Member
$\square$ Other:

\section{APPENDIX B. SURVEY Consent Form}

You are invited to participate in a survey on your experiences using the University of Minnesota Libraries Book Matchmaking Service. If you agree to participate, we would ask you to complete a series of multiple choice questions about your experience, reading habits, library use, and demographic information. We estimate the survey should take 5-10 minutes of your time.

We will not collect any personally identifying or confidential information, and only researchers will have access to the records. Participation in our survey is voluntary and does not impact your current or future relations with the University of Minnesota Libraries. If you chose to participate, you may quit at any time.

If you have questions, you may contact any of the researchers. If you have any questions or concerns regarding this survey and would like to talk to someone other than the researchers, you are encouraged to contact the Research Subjects' Advocate Line, D528 Mayo, 420 Delaware St. Southeast, Minneapolis, MN 55455; (612) 625-1650.

I have read the information above and consent to participate in the Book Matchmaking Survey

$\square$ Agree

$\square$ Disagree

\section{Book Matchmaking Survey}

Q1: How much time do you spend each week reading books for fun during the semester?
$\square$ I don't read for fun during the semester
- 0-1 hours/week
-1-2 hours/week
- 2-3 hours/week
a 3-4 hours/week
4+ hours

Q2: How much time do you spend each week reading books for fun during school breaks?

$\square$ I don't read for fun during school breaks
$\square$ 0-1 hours/week
$\square$ 1-2 hours/week
$\square \quad 2-3$ hours/week
$\square \quad 3-4$ hours/week
$\square$ 4+ hours


Q3: Where do you usually get the books you read for fun?

(Please select all that apply.)

口 Borrow through a U of M Library (including interlibrary loan)

$\square$ Borrow from a public library

$\square$ Borrow from a friend

$\square$ Purchase

- Other (please describe):

Q4: Why do you read for fun? (Choose all that apply.)
$\square$ Relieve stress
$\square$ Practice language/vocabulary
$\square$ Entertainment
To be able to talk about books with others
口 Procrastinate on other tasks
$\square$ Personal enrichment
$\square$ Other (please describe):

Q5: How often do you visit one of the U of M Libraries in person? (e.g, for study space, check out books, get help, visit a coffee shop)

$\square$ Daily

- Weekly

Monthly

$\square$ Once per semester

$\square$ Never

Q6: How often do you use online resources through the U of M Libraries?
$\square$ Daily
$\square$ Weekly
$\square$ Monthly
$\square$ Once per semester
$\square$ Never

Q7: Did you read any of the Book Matchmaking suggestions you received?

$\square$ Yes, I read one.

- Yes, I read more than one.

$\square$ No, but I still plan on reading one or more when I have time.

$\square$ No, I don't plan on reading any of the books suggested.

Q8: Did you check out any of the Book Matchmaking suggestions you received from a $\mathrm{U}$ of M Library?
$\square$ Yes
a $\mathrm{No}$

Q9: Would you recommend the Book Matchmaking service to a friend?

$\square$ Yes

$\square$ No

Q10: Please rate how you agree with the following statements (1 being strongly disagree and 5 being strongly agree):

- Participating in Book Matchmaking was fun.

I I am more likely to visit a U of M Library after participating in Book Matchmaking.
口 Participating in Book Matchmaking reduced my stress.

$\square$ Getting my suggestions encouraged me to pick up a book to read for fun.

$\square$ I am more likely to ask a librarian a question after participating in Book Matchmaking.

$\square$ I consider the $\mathrm{U}$ of $\mathrm{M}$ Libraries a source for future fun reading.

$\square$ I was satisfied with the suggestions I received from Book Matchmaking.

Q12: Is there anything else you'd like us to know about your experience with Book Matchmaking?

Q13: How old are you?

17 or under

प $18-22$

口 23-29

प $30-39$

- $40-49$

口 50-59

a 60+

Q14: What gender do you identify with?

口 Male

$\square$ Female

Other (please enter):

$\square$ I prefer not to respond.

Q15: What is your racial and/or ethnic identification? (Select all that apply.)

口 American Indian or Alaska Native

$\square$ Asian

$\square$ Black or African American

$\square$ Hispanic or Latino

- Middle Eastern or North African

$\square$ Native Hawaiian or other Pacific Islander

$\square$ White

$\square$ Other (please enter):

I I prefer not to respond

Q16: Which of the following best describes your status when you filled out the Book Matchmaking form?

$\square$ Undergraduate student

$\square$ Master's student

$\square$ PhD student

$\square$ Professional/Non-Degree seeking student

$\square$ Staff

I Faculty

$\square$ I graduated from the University of Minnesota (Alumni)

$\square$ UMN Friends of the Library Member

I I'm a community member 